\title{
A BIBLIOGRAPHY OF THE BANANA ROOT-WEEVIL
}

\author{
By MLortialer D. Leonard
}

The banana root-weevil, Cosmopolites sordidus Germar', is wideiy distributed thruout the Tropies, its distribution apparently being coincident with that of its only host plants-all species and varieties of bananas and plantains, MIusa spp. Altho it is not a serious pest thruout its whole range the insect is always of sufficient importance so that its presence is viewed with alarm, for bananas and plantains are a staple food with the natives wherever they are grown and of course are a large export crop in some countries.

The literature dealing with the banana root-weevil is widely scattered in the agricultural journals and annual reports and bulletins of the departments of agriculture and agricultural experiment stations of the tropical countries of the world. To compile the present bibliography has, therefore, been no small task. Its publication is believed worth while since many of the papers included are not readily obtainable by most of the workers in tropical countries with limited library facilities.

An attempt has been made to list every reference it was possible to find in which this insect was mentioned. The relative value of each article is indicated by an annotation following the reference. A total of 215 titles is given, of which the writer has been able to personally examine all but 23 ; these latter are marked with an asterisk. In some cases the original publication was not seen but careful typewritten copies were received thru the courtesy of Prof. C. R. Crosby of Cornell University, Miss Mabel Colcord, Librarian of the United States Bureau of Entomology, and the Librarian of the United States Department of Agrieulture. Acknowledgments are made to the above for this very necessary assistance as well as to the librarians of Cornell University and to Mr. A. J. Nrutchler of the American Museum of Natural History for much help in looking up references.

Anonymous. 1916. Agricultural division. Rept. Dept. Agr. Fiji for 1915. Council Paper No. 29:5.

Injury briefly mentioned. 
1916. A new banana pest. Jour. Jamaica Agr. Soc. 20: 25-26.

First discovered and doing eonsiderable injury to t-aere piece in Upper St. Andrew. Brief account; injury deseribed; no remedies.

1916. Banana borer weevil. Jour. Jamaica Agr. Soc. $20(11): 434-435$.

Borer increasing in St. Catherine; banana clean-up order suspended because of undue hardship its full enforcement, would entail.

*1916. Proclamation concerning the black weevil borer of bananas. Jamaica Gaz. Extraordinary, 28th. April.

"Orders destruetion by fire or otherwise of banana and plantain plants or parts of plants infected by the black weevil borer (Cosmopolites sordidus). No suckers may be planted on or removed from land found to be infested with this weevil." (Rer. Appl. Ent. 4:320, 1916.)

* 1916. Dealing with the banana borer in Jamaica. Daily Gleaner, Kingston, Jamaica, 21st. March, pp. 13-14.

Report of special committee on banana borer of Jamaica Agr. Soc. Recommends destruction of infested suckers, planting infested land with cane or bush for a few years and planting or encouragement of bush between slightly infested or clean land. (Rev. Appl. Ent. 4: 255, 1916.)

* 1916. Black borer beetle which is attacking banana trees. Daily Gleaner, Kingston, Jamaica, 22nd. April, p. 6 .

"An investigation is being made as to the areas in Jamaica on which Cosmopolites sordidus oceurs that these districts may be declared infested and an orler issued making this insect a notifiable one. It is proposed to introduce Irom Fiji the Histerid beetle, Plaesius javanus Er., which is predaceous on this weevil." (Rev. Appl. Ent. $4: 256,1916$.)

1916. Banana boring weevil. a new pest in bananas. Jour. Jamaica Agr. Soc. 20:103.

Brief refierence to a former notice.

1916. The black borer weevil of banana. Jour. Jamaiea Agr. Soc. $20: 145-146$.

Refers briefly to appointment of a committee of the Board of Managers of Agr. Soc. to recommend proeedure 
to Government. Suggested declare it pest or notifiable pest. Besides St. Andrews found in St. Catherine, but not bad.

* 1917. Banana borer. Jour. Jamaica Agr. Soc. 21(5): 169-173.

Extensive memorandum of Commissioner of Agrieulture for the West Indies, Sir. Francis Watts; believes ean be prevented from becoming serious by careful cultivation; trapping and selection of only healthy corms suggested. (Rev. Appl. Ent. 5: 435, 1917.)

1917. Banana borers. Banana beetle trap. Jour. Jamaica Agr. Soc. 21:230-231.

Brief; recommends clean entivation and vigorous plants: young plants worst infested. Trap of $1 / 2$ bulb kept fresh caught many beetles in one section.

* 1918. Agricultural Experiments. Jamaica Dept. Agr. Ann. Rept. for year ended 31st. March 1918, pp. 14-18.

Recommends submerging banana suckers in water for 48 hours; trapping the adults and kecping fowls on small plantings; carbon bisulfide kills the plants. (Rev. Appl. Ent. 7: 85, 1919.)

1918. Order relative to the black weevil borer of bananas. Jamaica Gaz. Extraordinary, 11th May.

Revokes proclamation ordering destruction of infested banana and plantain plants. (Rev. Appl. Ent. 6: 320, 1918.)

* 1918. Work connected with inseet and fungus pests and their control. Rept. Agr. Dept. St. Lucia 1917-1918, pp. 5-15.

Report on trip made by Dr. J. C. Hutson to investigate habits of $C$. sordidus; nature of damage and importance described in detail; recommends good cultivation and several other obvious remedies. (Rev. Appl. Ent. 6: 514, 1918.)

1919. Disposiciones vigentes sobre el servicio de sanidad vegetal. Cuba, Sec. Sanidad Vegetal, Circ. 5, p. 23.

Leaves and shoots of bananas proeeding from Jamaica prohibited entry on account of $C$. sordidus.

1919. Banana Borer. Jour. Jamaica Agr. Soc. 23(4) : 13'i.

Brief; soak bulbs in water for 24 hours and trap, examining the traps every 3 or 4 days. 
1921. Entomología. Bol. Asoc. Ag'r. Ecuador 1(3), 2 pp. Mentioned as having been found [by H. K. Plank].

1921. Work connected with insect and fungus pests and their control. Rept. Agr. Dept. St. Lucia, 1920, p. 3.

Brief; weevil borer chiefly responsible for patches of dying bananas in poasants' holdings thruout the island; recommends destroying infested plants and clean cultivation.

1922. Os insectos damninhos XXII-Uma coleobroca da bananeira, Cosmopolites sordidus. [Injurious insects XXIII-A Coleopterous banana borer, C. sordidus]. Chacaras e Quintae's 26(3):197-198, 5 figs.

Brief general account.

1922. Work comnected with insect and fungous pests and their control. Rept. Agr. Dept., St. Vincent for 1921, p. 24 .

"Caused a fair amount of damage on one plot of bananas."

1923. The banana borer (Cosmopolites sordidus). Agr. Cire. Dept. Agr. Fiji 3(4) : 59-60.

Briefy mentioned as widely distributed axd destruetive in in Fiji.

1923. Banana borer order, 1923. Jour. Jamaica Agr. Soc. 27(11-12), p. 1022.

Must not leave banana or plantain neglected or uncultivated. Cut infested plants into $3 / 4$ inch thick pieces and scatter over soil.

1924. The banana and its eultivation, with special reference to the British Empire. Bull. Imp. Inst. 22(3): $319-320$.

Brief general account; recommends trapping, selection of uninfested bulbs for replanting and removal of old stumps. of plants after larrest.

1924. Banana borer control. Agr. Circ. Dept. Agr. Fiji $5(1): 75-76$.

Plaesius jatanus, introrluced 11 years previously, now wall established. 
1924. Report of the division of entomology, fiscal year 1923-24. Ann. Rept. Ins. Exp. Sta. Porto Rico for 1923-24, pp. 97-98.

Trapping at the Station planting, continued from August to June, showed great reduetion in numbers of weevils collected but indicates necessity of contimuous trapping if borer injury is to be reduced to a minimum.

1924. Work comnected with insect and fungus pests and their control. Rept. Agr. Dept. St. Vincent for 1923, p. 29.

"Found in some few instances attacking banana plants."

1925. Banana beetle borer (Cosmopolites sordidus). Agr. Cir. Dept. Agr. Fiji 5(2): S8.

Brief note on injury and extension of regulations to several additional islands.

* 1925. Proclamations under the plant diseases act. Govt. Gaz. [New South Wales] No. 97.

Listed as a pest for purposes of the Act. (Rev. Appl. Ent. 13:639, 1925.)

1925. Banana root-stock borel. Farming in S. Africa $1(6): 209$.

Reeords first discovery of C. sordidus in South Afriea in 1924 in Natal and quotes from Me Carthy's account in Agr. Gaz. N. S. Wales (1920).

1927. Libya: decree of 13 th. September 1926 on importation of plants. Internat. Rev. [Sci. \& Pract.] Agr. N. S. 18(3) : T187-T188.

Brief note; banana plants from erery source prolibited importation on account of $C$. sordidus.

1927. Cuarentena exterior Num. 7. Bol. Mens. Defensa Agr. Sec. Agr. y Fomento, Néxico 1(7) : 536-537.

Note stating that importation of banana plants or parts from foreign countries is prohibited on account of $C$. sordidus.

* 1927. New South Wales: Plant Diseases Act. 1924. Regulations Nos. 27-31. Govt. Gaz. No. 168, reprint, $2 \mathrm{pp}$.

Banana plants restricted in movement and infested plants to be treated in several ways. (Rev. Appl. Ent. 16:124, 1928.) 
* 1928. New South Wales: Proclamation under the plant diseases act, 1924. Govt. Gaz. No. 128, reprint, 1 p.

Prohibits introduction of banama, plantain or manilla hemp plants or plant parts, except under permit on account of C. sordidus. (Rev. Appl. Ent. 17: 103 1929.)

1929. Report of the division of entomology, Ann. Rept. Ins. Exp. Sta. Dept. Agr. \& Labor Porto Rico for 1927$1928: 95$.

\section{Brief note.}

1930. Division of Entomology. Rept. Comm. Agr. and Labor Porto Rico for fiscal year ended June 30, 1929, p. 700 .

Note stating that studies have been marle; damage is serious.

Ballou, H. A. 1912. Insect pests of the Lesser Antilles. Imper. Dept. Agr. West Indies, Pamphlet Ser. 71, p. 112. Brief mention.

1916. The banana weevil. Agr. News [Barbados] 15 (364) : 123 .

Brief aceount of general distribution, habits and spread; recommends destroying all infested stools and replanting only uninfested ones.

1922. Insect pests of plantains and bananas. West Ind. Bull, 19(2): 26 .

Listed as generally distributed and doing severe damage in St. Lueia, B. W. I.

1928. Control of insect pe'sts. Rept. St. Lucia Agr. Dept. for 1927, p. 10.

Mentioned as eausing bananas to be treated by the Banana Inspectors.

1929. Diseases and pests within the colony. Rept. St. Lucia Agr. Dept. for 1928, p. 14.

Mentioner as a pest in order to comply with requirements of the Plants Protection Ordinance.

1931. Banana borer. Jour. Jamaica Jour. Agr. Soc. $35(2): 63$.

Still doing considerable damage in some centers while in others reasonably well controlled: urges covering crown of 
growing plant with earth and also butts after eutting back to the crown; also systematic trapping and eleaning un debris and ehopping up of stumps within one month after harvesting banatus.

Barrett, 0. W. 1928. The Tropical Crops, pp. 182-183.

Brief statement of nature and extent of damage.

Benson, A. H. 1920. Remedies suggested [for the banana weevil.] Queensl. Agr. Jour. 13(4) : 168.

Brief description of precautionary measures, destruction of beetle in infested plantations, and how to destroy infested plants.

Brugiroux, A. 1928. French Settlements in Oceania: some insects damaging erops. Internat. Rev. [Sei. \& Pract] Agrie. $19(4): 400$.

C. sordidus listed as a pest in Talniti.

Carment, A. G. 1922. Report on mycological work done by Dr. A. G. Carment, medical officer of health and bacteriology. Dept. Agr. Fiji. Amn. Rept. for the year 1921. Council Paper No. 56:8.

Brief note.

Charmoy, D. d' E. (See d' Emmerez de Charmoy.)

Cedaña, S. M. 1922. The banana weevil. Philippine Agr. $10: 367-376,2$ pl.

Good general account for the Plilippines; experimental data on injury, life history and control; a serious pest also of abaca (Mrsa textilis Nee.); bibliograplyy of 14 titles.

Chevrolat, A. 1880. Diagnoses de curculionides de la Martinique. Le Naturaliste 1:198.

Original deseription of Sphenophorus pygidialis listed doubtfully as a synonym of $C$. sordidus by Fletiaux and Salle who state that the single type specimen could not be foumd in the Chevrolat collection.

1885. Calandrides. Ann. Soc. Ent. France, Ser. $\ddot{\mathbf{w}}$, $5: 289-290$.

Cosmopolites described as new genus. Calandra sordida Germar given as type and said to oceur in Brazil, Java, Ceylon, Malacea, Snigon, China, Reunión, ete. 
Crosby, C. R. and Matheson, R. 1914. Catalogue of [injurious] insects. In Cyclopedia of Horticulture by L. $\mathrm{K}$. Bailey, 2 : 1049.

Listed as injurious.

Dammerman, K. W. 1929. The Agricultural zoology of the Malay Archipelago. The animals injurious and beneficial to agriculture, horticulture, and forestry in the Malay Peninsula, the Dutch East Indies and the Philippines, p. 98.

Brief general account; no eontrol; Placsius javanus ant Crysopilus fermginosus mentioned as predators. This English edition is a revised and enlarged one based on the work in Dutch of about the same title published in 1919 in Amsterdam

de Azevedo Marques, L. A. 1922. A praga de bananeira no Río de Janeiro. (Biología de Cosmopolites sordidus Germ.). Bol. Soc. Ent. Brazil, 1922(1,2,3):24-32, 2 figs.

Good, rather brief account of life history and control; first recorded in Brazil in 1918. Egg period deternined as 8 ditys, larval 22, and pupal as 10 , and various contril measures diseussed, including use of earbon bisulfide.

1923. A praga de bananeira no Rio de Janeiro. (Biologia do Cosmopolites sordidus Germar). Bol. Minist. Agr. Ind. e Comm., 11(5) : 109-117, 2 pls. (Dec. 1922).

Stages, life-cycle (40 days) and habits described; various measures recommended, including carbon bisulfide.

d' Emmerez de Charmoy, D. 1928. Entomological divsion. Ann. Rept. Dept. Agr. Mauritius for 1927, p. 1? (Port Louis).

"Bananas were reported as in previous years to be severely attacked with the stem beetle, Cosmopolites sordidus. Instruetions for coping witl the pest were issued to those concerned.

d'Emmerez de Charmoy, D. and Gebert, S. 1921. Insect pests of various minor crops and fruit trees in Matritius. Bull. Ent. Res. 12(2) : 190.

"Banana.-The black banana weevil, C. sordidus Germ. is the only pest. The larvae live in the root-stock and oceur 
sometimes in such great number's as to cause the death of the plant. The varieties known as 'Gingeli' and 'Banana Carre' are particularly affected."

de Seabra, A. F. 1920. Etudes sus les maladies et les parasites du cacaoyer et d' autres plantes cultivées á $\mathrm{S}$. Thomé. 22. Le Cosmopolites sordidus Germ., á S. Thomé. Lisbon, Companlia Agr. Ultramarina, pp. 3- $\tau$.

General account of in the Island of San Thomé; known as a pest since 1907 .

1922. Etudes sur les maladies et les parasites du Cacaoyer et d'autres plantes cultivées a $\mathrm{S}$. Thomé. No. 22. Le Cosmopolites sordidus Germ. a S. Thomé. Mém. publ. par Soc. Portugaise Sci. Nat., Sér. Zool. No. 2, fasc. 2 : 101-104, 3 figs.

Brief account of nature of damage, detailed deseription (with figures) of the adult, with a note on several color variations; states it was recorded by Gravier in $\mathrm{S}$. Thomé in 1906.

* 1922. Insects de $S$. Thomé provenant de la mission a' étude du Professeur Sousa da Camara en 1920.-Separate from Anais do Instituto de Agronomia, $21 \mathrm{pp}$., Coimbra, Portugal.

Recorded as attacking banana. (Rev. Appl. Iint. 11: 308. 1923.)

Dejean, P. F. MI. A. 1837. Catalogue des coleoptéres, 3rd. ed. p. 329.

Calandra striata Petit listed from Brazil; is also listed in 2 nd Ed. p. 304 but I have not seen a copy of this edition.

Despeissis, A. 1924. Dept. Agr. Fiji Ann. Rept. for the year 1923. Couneil Paper 53:3-4.

$P$. javanus has become established over an extensive area on the Rewa River and its tributaries; sanitation recommended.

Drieberg, C. 1916. Ceylon Agricultural Society; progress report 49. Trop. Agr. (Peradeniya) 46(3): 191.

Note recording a plantain shoot received from Uda Alu deniya as infested. 
* Dupont, P. R. 1915. Insect notes of curator, Botanic Station, Sychelles, 18th. March.

A consignment of Gros Miehel banana suckers imported from Fiji were infested. (Rev. Appl. Ent. 3: 410, 1915.)

* 1918. Insect Notes. Curator's Report on Botanic Station, Seychelles, for 1917. (MS from Colonial Office, received by R. A. E. 24th. June, 1918.)

Reported that bananas were badly infested. (Rev. Appl. Ent. 6: 377, 1918.)

Edwards, W. H. 1925. Tse eharançon du bananier, Cosmopolitis sordidns Germ. Rev. Agr. de l' ̂le Maurice, No. 22 : $513-514$.

Most important banana pest in Mauritius; length of stages given; best control is- burn all suspected plants, plant only healtly corms and use bait traps of piees of corms.

Fahraeus, 0. J. in C. J. Schoenherr's (1845) Genera et species eurculionidum, cum synonymia hujus familiae, $8(2): 251-252$.

Original description of Sphcnophorus striatus from Brazil.

Fawcett, W. 1913. The banana, its cultivation, distribution and commereial uses. (London), pp. 99-101.

Brief general account.

Fernández Garcia, R. 1930. [Informe del] Estación Experimental Insular. Seción de Entomología. Inf. An. Com. Agr. y 'Trah. año fiseal 1929-1930:181.

Brief note on beneficial results obtained by "cleaning" infected suckers with a knife; reduction of weevils by trapping and suggestion that attempt be made to introduce the predators, Placsius javanus Er. and Chrysopilus fermginosus Weid.

Fletcher, T. B. 1914. Some South Indian Insects, pp. 342. 343, 1 fig.

Brief account; recorded from Malabar, Coimbatore, Godavari and Ganjam; usually a minor pest of plantain but oceasionally doing considerable damage; destroy oId stumps and use only uninfested suckers.

1917. Rept. Proc. Second Ent. Meeting held at Pusn, pp. 238-239.

Brief notes on distribution (thruout S. India and in W. 
India as far north as Poona); destroy old infested stumps and select only non-infested suckers.

1920. An annotated list of Indian crop pests. Proc. Third Ent. Meet., Pusa 1:208.

Briefly recorded as a pest in eertain parts of India and Ceylon.

*Fletiaux, E. 1903. Les Insects. Agr. Prat. Pays Chauds $2(10): 495-502$; (12) : 745-760.

Fletiaux, F. and Sallé, A. 1889. Coleoptéres de la Guadeloupe. Ann. Soc. Ent. France, Sér. 6 Vol 9: 455.

Listed as having been found in severnl localities in the island and as being common in rotten bananas. Four synonyms given-striatus Fahrs, erenatus sturm., javanus Westerman in litt.) and doubtfully, pygidialis Chev.

Freeman, W. G. 1924. Plant Pathology. Rept. Dept. Agr. Trinidad and Tobago, for year ended Dec. 21st. 1924, p. 24.

"Continued to be a pest in all distriets and during the year was recorded for the first time from Tobago."

Froggatt, W. W. 1919. The black banana stem weevil (Cosmopolites sordidus Germ.) Agr. Gaz. New South Wales $30(11)$ : 815-818, 6 figs.

Apparently first or at least one of earliest records of pest in New South Wales. Brief account of distribution, lifehistory and stages; excellent figures.

Froggatt, J. L. 1921. Banana beetle borer investigations (First Progress Report). Queensl. Agr. Jour. 16(3): $200-208,4$ pls.

Report on the first half year's investigations on habits and life-listory of the insect; control brief.

1922. The banana beetle borer, Comopolites sordidus Chev. (Cureulionidae). (Second Progress Report.) Queensl. Agr. Jour. 17(1) : 39-45, 2 figs.

Brief description of life-history; habits and stages; detailed life-history data.

1922. Banana beetle borer. Queensl. Agr. Jour. 17(5): 240-242, 2 figs.

A brief resumé of information obtained to date on injury, life-history and control. mis 
1922. The banana beetle borer. Queensl. Agr. Jour. 18 (1) $: 48-49$.

Information on nature of injury, life-listory and control, mostly quoted from previous reports.

1922. The banana beetle borer III. Queensl. Agr. Jour. 18(4) : 279-288, 3 pls.

Life-listory, injury and experiments of tests of chemicals to kill beetles with baits of corms; control measures outlined.

1923. The banana beetle borer. IV. Queensl. Agr. Jour. $19(2): 68-75,3$ pls., 6 tables.

Detailed life-listory and control experiments: 96 hours in water 90 per cent beetles still alive and remained so for 10 days. P.D.B. (Paradiclorbenzene) kills in confined space.

1923. The banana beetle borer. V. Queensl. Agr. Jour. $19(6): 523,5$ pls.

Good aceount-life history and control experiments. Paris green best on slieed corms; after feeding 18-48 hours 99.4 per cent beetles died; sodium arsenite powder killed 92.5 per cent in 18-54 hours.

1924. The banana weevil borer. Queensl. Agr. Jour. 21(4) : 275-276.

Brief report of three years' investigations to-date on lifehistory and habits.

1924. Banana weevil (Cosmopolites sordidus Chev.). Queensl. Agr. Jour. 21(5):369-378, 2 pls.

Sixth progress report; beetles went 121 days without food; detailed account of experiments to date.

1924. Banana weevil borer. Queensl. Agr. Jour. 22(3): 154-156.

Brief summary of previous observations and experiments with detailed control recommendations based thereon; stated that liberation of Plaesius javanus, the predatory Fisterid beetle from Java, is being eontinued on a small area near Brisbane and several adults found $2-3$ months after liberation. 
1925. The banana weevil borer (Cosmopolites sordidus Chev.). Queensl. Agr. Jour. 24(6) :558-593, pls. 14v148.

One of the best full accounts of this insect.

1926. The Banana Weevil Borer. Queensl. Dept. Agr. and Stock Div. Ent. and Plant Path. Bul. 4(N.S.) 40 pp., 9 pls.

Excellent full account for Queensland.

1928. Notes on banana insect pests. Queensl. Dept. Agr. and Stock, pp. 1-2.

Brief statement of nature of damage, varieties infested and generaI world distribution.

1928. Baiting for banana weevil control. Queensl. Depts. Agr. and Stock, 2 pp.

Materials and method deseribed.

1928. Baiting for banana weevil borer control. Queensl. Agr. Jour. 29(4) : 282-283.

Detailed description of low to make and use bait traps for catehing adults.

1928. The banana weevil borer in Java with notes on other crop pests. Queensl. Agr. Jour. 30:530-541, 1 pl.

Same as Div. Ent. and Plant Patll. publication which follows.

1928. The banana weevil borer in Java with notes on other crop pests. Div. Ent. and Plant Path., Dept. Agr. and Stock, Queensland, 12 pp., 1 pl.

Economic status in Java with notes and descriptions of the predators-Chrysopila fervuginosa Weid. and Plaesius javanus Er.-and their introduction into Queensland.

Germar, E. F. 1824. Coleopterorum novae aut minus eognitae descriptionibus illustratae, 1, (Coleoptera) p. 299, 2 pl. (Halae).

Original description as Calandra sordida; habitat given as the East Indies ("India orientali"). 
Ghesquiére, J. 1924. La maladie des bananiers dans le Bas-Congo. Bul. Agr. Congo Belge 15(1):171-172.

C. sordidus continuing to spread; first found near Zobe about 1913-14 and now found from the extreme west of Mayumbe to near Kisantu.

1925. La maladie du bananier au Congo Belge. (Notes complémentaires.) Bul. Agr. Congo Belge 16(3-4) : $556-560$.

Brief general account.

1927. La maladie du bananier au Congo Belge. Rev. Zool. Bot. Afr. Suppl. 15 (Bull. Cercle Zool. Congolais 4(1) : [59]-[68], 1 fig.

Good account of insect and eontrol in Belgian Congo. 17 references.

González Ríos, P. 1922. El gorgojo del banano. Rev. Agr. Puerto Rico 9(6):39-42, 3 figs.

Brief general account for farmers in the Island, describing recent discovery and giving life-history, nature of injury and suggesting urgent need for prevention of spread.

1930. Cultiwo del banano en Puerto Rico. Est. Exp. Ins. P. R. Bol. 36:49-51, 2 figs.

Bricf general account for Porto Rico.

Goodman, W. S. 1929. Report of the Plant Breeder. Ann. Rept. Jamaica Dept. Agr. for Year Ended 31st. Dec. 1928, p. 13.

Brief; trapping has given good $\cdot$ results.

Gowdey, C. C. 1920. Report of the government entomologist for 1918-1919. Uganda Dept. Agr. Ann. Rept. for year ended 31st. March 1919, p. 39.

Occur's not only on mainland but also on Bukassa Island, Sesse Group, which has been uninlabited for years; always worse on old uncultivated plots; recommends good cultivation and sanitation and rearing of the predaceous Histerid beetles.

1921. Annual report of the government entomologist. Ann. Rept. Jamaica Dept. Agr., for $1920: 25-27$.

Brief note-favored by: poor soil, cultivation, land on bananas for long period, failure to destroy old bulbs and 
exeessive mulehing; recommends cultivation, rotation and systematic trapping.

1922. [Annual report of the] Government entomologist. Ann. Rept. Jamaica Dept. Agr. 1921: 40.

Briefly notes several attacks which were investigated; due to planting infested suckers but in one planting control measures greatly lessened trouble.

1922. The banana borer, (Cosmopolites sordidus Germar). Jamaica Dept. Agr. Ent. Cire. 8, 8 pp., 2 pls.

General account; original life-history data with control; bibliograplyy of six titles; the Histerid beetle predator, Plaesius javanus, not very suceessful.

1923. The principal agricultural pests of Jamaica. Dept. Agr. Jamaica Ent. Bul. 2:24-27, 2 pls.

Full account with control measures.

1923. Report of government entomologist, Aun. Rept. Jamaica Dept. Agr. 1922: 23.

Brief account; increasing in certain distriets, but trap method satisfactory wherever systematically carried. out.

1924. Report of the government entomologist. Ann. Report. Dept. Agr. Jamaica, 1923:20.

Brief; very prevalent-a dry year; paris green and sodium arsenite on corms gave $80-90$ per cent kill of weevils in 24 hours; suckers in water for 24 hours killed a certain number of all stages.

1925. Report of the government entomologist. Anr. Rept. Jamaica Dept. Sei. and Agr. for year ended 31st. Dec. 1924, pp. 17-18.

Three new localities infested, but situation in general greatly improved due to trapping and destruetion of old bulbs.

1926. Report of the government entomologist. Ann. Rept. Jamaica Dept. Agr. for year ended 31st. Dec. 1925, p. 10, 11.

Control improving and no new localities infested; mention of experiments being condueted with paradichlorobenzene. 
1927. Report of the govermment entomologist. Ann. Report. Jamaica Dept. Agr. for year ended 31st. Dec. 1926, p. 16.

Reported from two new localities; experiments with paradichlorobenzene reported to appear somewhat promising.

1928. Report of the government entomologist. Ann. Rept. Jamaica Dept. Agr. for year ended 31st. Dec. 1927 , p. 20.

One new Iocality infested; experiments with a crude paradichlorobenzene continued and on one property 75 to 85 per cent effectiveness was obtained.

Gravier, Ch. 1907. Sur un coléoptore (Spenophorous striatus Fahr.) qui attaque les bananiers a San-Thomé (Golfe de Guinée). Bul. Mus. Nat. d' Hist. Nat., Paris, 13 : $30-32$.

Brief account of the banana root weevil (as Sphenophorus striatus Fahr.) in San Thome where he states it is considerable of a pest; nature of injury briefly deseribed and the account by Acacio Magro abstracted, who recommends chiefly immersion [of infested plants or bulbs ?] in Bordeaux mixture.

Gyllenhal, L. 1838 in Schoenherr's Genera et species curculionidum 4(2) : 925-926.

Technical description; habitat given as Java; from collection ("A. Dom.") Schuppel and Westermann.

Hadden, F. C. 1928. Some injurious insects of Formosa. Jour. Pan-Pacif. Res. Inst. 3(1) : 14.

"Bananas are attacked by c. sordidus, a recently aceidentally introdtueed root and stalk beetle borer".

Hancock, G. L. R. 1926. Annual report of the assistant entomologist. Ann. Rept. Dept. Agr. Uganda, 1925, p. 28.

Listed as injurious.

Hargreaves, $\boldsymbol{H}$. 1922. Anmual report of the government entomologist, 1921. Uganda Dept. Agr. Ann. Rept., 1921: 62 .

"NTo serious outbreak of this pest has been noticed. Larvae and pupae found on fying stems from which fruit had been eut." 
1924. Ann. Rept. of the government entomologist. Uganda Ann. Rept. Dept. Agr. 1923, p. 19.

"Reported to be present in large numbers on two areas. Cutting out and destruction of infested stocks and the collection of adult weevils by means of trap stocks was recommended."

1925. Annual report of the government entomologist. Uganda Amn. Rept. Dept. Agr. 1924, p. 25.

Forty per cent of plantain trees in a garden infested.

1926. Report on the entomological section. Ann. Rept. Lands \& Forests Dept. Sierra Leone for 1925, p. 16.

Listed as attacking bananas.

1928. Annual report of the government entomologist. Rept. Dept. Agr. Uganda, 1927, 11 pp. typescript.

Brief statement that a widespread outbreak of $C$. sordidus oceurred on plantain and banana but the natives did little or nothing to control the pest.

(?) Harris, W. 1916. Report of the superintendent of public gardens. Suppl. to Jamaica Gaz. 39(7):118.

"Found to be attacking a small area of banana on the hillside west of the gardens but none of the plants in the gardens were attacked. It was deeided however to destroy all plants on the garden lands."

Hopkins, G. H. E. 1927. Pests of economic plants in Sa. moa and other island groups. Bul. Ent. Res. 18(1): 28.

"Swezey found this species attacking bananas and suggested that it was then recently established. It is still by no means common and does little damage."

Howard, L. O. 1930. A history of applied entomology (Somewhat annecdotal). Smith'sonian Miscl. Coll. Vol. 84 (whole volume) Publ. 3065, pp. 413, 513, 523.

Brief mention of introduction of the Histerid beetle, Placsius javanus into Fiji and later into Queensland, in both as predators of the banana root-weevil.

Hutson, J. C. 1921. Report of the division of entomology, April-June, 1921. Trop. Agr. [Ceylon] 57(3): 194.

"Found to be prevalent [in the plantain districts] especially in plantations which are allowed to run more than two years withont replanting. The work is being carried on," 
1922. Report of the entomologist. Ceylon Dept. Agr. Rept., 1921: C. 23-26.

Brief: stated as prevalent in two areas injuring plantains; usually worse where no planting has been done for several years.

Jardine, N. K. 1924. Plantain root beetle borer. Dept. Agr. Ceylon, Leaflet 29, 1 p. 1 pl.

Brief account of life-history and control.

(?)1924. Plantain root beetle borer (Cosmopolites sordidus Germar). Yearbk. Dept. Agr. Ceylon, 1924, pp. 55-58.

Brief general account, mostly compiled from literature; trapping recommended.

* Jepson, F. P. 1911. Report on economic entomology. Fiji Dept. Agr. Council Paper 25, 89 pp., 7 pls.

1914. A mission to Java in quest of natural enemies for a coleopterou's pest of bananas (Cosmopolites sordidus Chev.). Dept. Agr. Fiji Bul. 7, 18 pp., 3 pls.

General distribution; life-history in Fiji, labits and stages described of Plaesius javanus Er., Chrysopilus forruginosus Wied. and data on amount of $C$. sordidus larvae eaten by them; transportation of beetles to Fiji; five references eited.

1915. Division of entomology. Dept. Agr. Fiji. Ann. Rept. for 1914: 20 .

Less abundant than in previous years, especially in distriets in which the predaceous Histerid beetles from Java (Plaesius javanus) had been established; data on status of $P$. javanus since introduction.

1916. Report on a visit to the Rewa River plantations. Dept. Agr. Fiji Pamphlet 25, p. 1.

Less prevalent than three years previously due to exceptionally wet season; conditions conducing to its spread are: poor drainage; neglect in planting only healthy suekers; failure to rotate often enuf; planting too close and leaving infested stems and stumps on ground.

1917. Division of entomology. Dept. Agr. Fiji Ann. Rept. for year 1916. Council Paper 107:16.

Continued to be injurious to some plantings but apparently less so than formerly. 
1919. Division of entomology. Fiji Dept. Agr. Ann. Rept. for the year 1918. Council Paper No. 32:15.

Another importation of the predaceous beetle, Plaesius javanus from Java was received.

1.924. Report of the acting entomologist. Ceylon Administ. Rept. Dept. Agr. 1923, p. D-20.

"The platain root borer (Cosmopolites sordidus) continues to cause considerable damage to plantains in the Rambukana and Matale Districts."

Jepson, F. P. and Knowles, C. H. 1920. Division of Entomology. Ann. Rept. Fiji Dept. Agr. for the year 1919. Council Paper No. 65. pp. 7-14.

Outline of proposed investigations.

Kermack, James. 1930. Fruit production for export.Part II,-cultivation of the banana in Fiji. Agr. Jour. Dept. Ag'r. Fiji 3(1):36-37.

Recommends trapping weevils; Plaesius javanus is proving a successful predator.

Knowles, C. H. 1907. Agriculture (Report on, for the year 1906). Legislative Council Fiji. Council Paper No. 13, p. 7.

Appears to have been present for some time and becoming more common; destroy infested plants.

1909. Agriculture (Report on, for the year 1908) Legislative Council Fiji. Council paper 27, p. 20.

Injurious during the year; carbon bisulfide recommended.

1911. Agrieulture (Report on. for the year 1910) Fiji. Council Paper No. 23, p. 5.

Mentionerl.

1918. Division of entomology. Fiji Dept. Agr. Ann. Rept. for 1917. Council Paper No. 60: 8-9.

Prevalence and amount of damage; injury mostly on outer half of bulb; trapping and cultivation recommended; $P$. javanus introduced in 1913, not seen during 1917 .

1919. Inspection of plantations. Fiji Dept. Agr. Ann. Rept. for the year 1918, Council Paper 32, p. 11.

Reported as much nore plentiful during the year than formerly. 
1919. Division of Entomology. Fiji Dept. Agr. Ann. Rept. for 1918, Suva, Council Paper 32:13-14.

Serious damage during the year; generally distributed througlout the Colony; experiments shows that traps are effective but must be destroyed every 21 days; old infested plantations should be ploughed out; Plaesius javanus in two consignments reintroduced furing year.

1920. Agricultural work of the department. Fiji Dept. Agr. Ann. Rept. for the year 1919. Council Paper No. 65, pp. 5, 13.

Note on trapping beetles; beetle shows preference for West Indian plantains; is of the opinion that poor condition of plants in certain areas due to weevil.

1921. Entomological. Fiji Dept. Agr. Ann. Rept. for the year 1920. Council Paper No. 38, p. 8.

Continued injurions; Plaesius javanus slow in inereasing.

* Knowles, C. H. and Jepson, F. P. 1912. The banana in Fiji. Dept. Agr. Fiji Bul. 4, 17 pp., 3 pls.

Lawson, D. 0. K. 1917. The striped cane weevil. Jour. Jamaica Agr. Soc. 21(6) : 219-220.

C. sordidus mentioned in comection with brief discussion of control of striped cane weevil.

Leng, C. W. and Mutchler, A. J. 1914. A preliminary list of the Coleoptera of the West Indies as recorded to Jan uary 1, 1914. Bul. Am. Mus. Nat. Hist. 33, Art. 30:478.

Listed from Guadalupe.

1917. Supplement to preliminary list of the Coleoptera of the West Indies. Bul. Am. Mus. Nat. Hist. 37, Art. $5: 218$.

Listed from Dominica.

Leonard, M. D. 1931. Entomology in Puerto Rico during the past decade. Jour. Econ. Ent. 24(1) : 146.

Brief note on status in the island.

López Domínguez, F. A. 1927. Informe anual del director de la estación experimental Insular de Puerto Rico, año fiscal 1925-26, p. 48 .

Brief; has continued to spread as far as Utuado; Austra- 
lian method of dusting the corms with Paris green and flour will be tried next year.

Mackie, D. B. 1917. A summary of the work of the pest control section for the year 1916. Philippine Agr. Rer. $10(2): 137-138$.

Brief reference to death of a large number of abaca plants in Paete, Laguma.

1918. Some pests we do not want, why we do not want them, and how they may arrive. II. The banana root borer. Calif. State Comm. Hort. Bul. 7(8): 498-502 3 figs.

Refers to Federal quarantine 31. prohibiting entry of banana plants for propagation; general distribution, habits and injury described; especially in Plilippines, grubbing ont and burning infested plants recommended.

* Magro, Acacio. 1906. O musaphago ou bicho que ataca a bananeira pão; meies practicos de o destruir, San Thomé, 1906.

Mayné, R. 1916. Rapport sur une maladie des bananiers au Nayumbe (Bas-Congo). [Report on a banana plant disease at Mayumbe (Lower Congo) ]. Bull. Agr. Congo Belge $7(3-4)$ : 236-239.

Brief general account of the insect in Mayumbe.

MeCarthy, T. 1920. Banana root borer, (Cosmopolites sor. didus Germar). Agr. Gaz. New South Wales 31(12): 865-872, 2 pls., 1 fig.

Good general account but no experimental data ineluded

McCreadie, J. 1922. Nasinu Experimental Station. Overseer's Report. Ann. Rept. Fiji Dept. Agr. for the year 1921. Council Paper No. 56, p. 5.

Plants poor owing to attacks of beetle; large mumbers of beetles caught by trapping.

Misra, C. S. 1920. Index to Indian fruit pests. Proc. Third. Ent. Meet. at Pusa 2:593.

Listed as injurious to plantaiu. 
Moreira, Carlos. 1922. Broca da bananeira. Chacaras e Quintaes 25(3): 233-234.

Brief note regarding injury.

Moznette, G. F. 1920. Banana root borer. Jour. Agr. Res. $19: 39-46$, fig. 1 , pls. 8-11.

Good account of the insect in Florida based on experymental data; detailed description of the stages of the insect; destruction of infested plants and use of bait traps recommended.

Muir, F. 1907. Notes on the sugar-cane hoppers and borers in the Malay States and Java. Rept. work Expt. Sta. Hawaiian Sugar Planters' Assn. Div. Ent. Circ. 2, pp. 8-9.

Mentioned as being failly common in banana stems; stated that a large black Fisterid bectle and its larva as well as the larvae of certain Hydrophilids feed on larvae of $C$. sordidus.

1008. Entomological Work in Borneo. Rept. work Exp. Sta. Hawaiian Sugar Planter's' Assn. Div. Ent. Cire 4, p. 5 .

Mentioned as being found (in company witl Sphenophorus ferrugineus) in banana and palm trees, attended by Hydro. philid and Histerid beetle predators as in Java.

Muir, F. and Swezey, O. H. 1916. The cane-borer beetle in Hlawaii and its control by natural enemies. Rept. Haw. Sugar Planters' Assn. Expt. Sta. Ent. Bul. 13:15, 16 (and pp. 58, 61, 67).

(P. 15) Note on Placsius jaxamus being found as predaceous on $C$. sordidus and sent from Java to Honolulu; (p. I6) note stating that Chrysopila sp. larvae were numerous in sago palms and banana trees feeding upon beetle and dipterous larvae; Jepson's observations on both predators referred to. Fages 58, 61 and 67 are contained in reprints of Ent. Circulars 2 and 4 (See Muir 1907 and 1908).

Murray, P. W. 1918. Agricultural experiments. Suppl. to Jamaica Gaz. 41(9) : 182-184.

General account of distribution, labits, injury and control in Jamaica; burning diffeult; carbon bisulfide not practical on plants buried under soil; soaking suckers 48 hours in water effective; good cultivation and clean management all neeessary for effective control. 
Newell, W. 1919. Report of the plant commissioner for the biennium ending April '30th., 1918, and Supplemental Reports. Quart. Bul. Fla. St. Plant Bd. 3(2):47-49.

Found in one nursery and all banana plants there and in adjacent properties were destroyed.

1921. Report of the plant commissioner for the biennium ending April 30th., 1920, and supplementary reports. Quart. Bul. Fla. State Plant Bd. 5(2):94-95.

States that it is also known to attack sugar cane [this is undoubtedly in exror]; refers to eradication campaign in Manateo Co. in 1918 and of elimination of an infestations in Polk Co. in 1918; in Dade Co. in 1919 and 1920 several infestations were cleaned up and the State is ap. parently clean.

Newman, L. J. 1924. Report of economic entomologist. West Austr. Dept. Agr. Ann. Rept. for the year ended June 30,1924, p. 22.

"Two outbreaks of this weevil were recorded during the year in the North West. In both instances the North-West Department was advised to destroy by fire the whole of the plants. This was done and the outbreaks suppressed. Carnavon District still infested. The Southwest apparently not yet infested."

Ogilvie, L. 1924. Notes on plant diseases and pests. Agr. Bul. Bermuda Dept. Agr. 3(2):6.

Brief note: prevalent wherever bananas are grown in unsuitablo soil or are not properly cultivated; attention should be paid to proper cultivation, rotation of erops where possible and systematic trapping with baits of banana stems or bulbs, and traps examined every three days.

1924. Preliminary report of the plant-pathologist for: the period September 27th. to December 31st., 1923. Bermuda Repts. Bd. and Dept. Agr. 1923, p. 29.

Briefly stated as only of serious importance where bananas are grown in unsuitable soil or situation or are otlerwise weakened.

1928. The Insects of Bermuda. Dept. Agr. Bermuda, [unnumbered publication], p. 16.

"Of serious importance in Bermuda only where bananas are grown in unsuitable soil or situation or where the plants are otherwise weakened." 
Pierce, W. D. 1917. A manual of dangerous insects likely to be introduced in the Inited States through importation's, pp. 34, 207. U. S. Dept. Agr. Office of Sec'y.

Brief; life history; also lists sugar cane as a host [undoubtedly in error]; distribution is: Fiji, British West Guinea [in Eastern Femisphere south Paeific Ocean to Indian Archipelago] Jamaica, Tndia, Brazil.

Pinto, M. P. D. 1928. The two weevil pests of plantains. (Musa sapientum L.) Cosmopolites sordidus Germ. and Odoiporus longicollis Oliv. Trop. Agr. $70(4): 216-224$, figs. 1-5.

Life-histony and control for Ceylon; bibliograply of 7 titles.

Pynaert, L. 1921. Les bananiers. Bul. Agr. Congo Belge, $12(2): 249-251$.

Brief general accoutit with suggested eontrol.

Ramakrishna Ayyar, T. V. 1922. The weevil fauna of South India with special reference to specie's of economic importance. Agr. Res. Inst., Pusa, Calcutta, Bul. 125, p. 19 , fig. 1 , pl. 20 .

"Brief mention of $C$. sordidus as oceasionally injurious to the stems of growing banana plauts, but noted so far only in Malabar and the Northern Sircars."

1923. Some insects noted as pests of fruit trees in South India. Agr. Jour. India 18(1):50-59.

"Tho found in a few places in South India, has not yet assumed the status of a serious pest."

Reh, L. 1913. Die tierischen Feinde, in P. Sorauer's Handbuch der Pflanzenkrankheiten 3:566.

Mention.

Ritchie, A. H. 1916. Report of entomologist for year 1915-1916. Ann. Rept. Jamaica Dept. Agr. for year ended 31'st. Warch 1916, p. 33.

"The presence of the black weevil of banana (C. sordidus Germ.) in the Island was brought for the first time to the attention of banana plauters by the Entomologist in late November, 19íj. This insect has already formed the subject of independent and extended report." 
* 1916. The black beetle attacking banana cultivations. Daily Gleaner, Kingston, Jamaica, 22nd. January, p. 18, 2 figs.

Brief general aceount of distrilution and injury; coopexation in eontrol urged. (Rev. Appl, Ent. $4: 175,1916$.

1917. Annual report of the government entomologist for year 1916-1917. Suppl. to Jamaica Gaz. 40(4):97.

Very briefly summarizes a report submitted in Decembermention of the beneficial grub of Pyrophorus sp. (Elateridae); adults lived in banana trash in the laboratory for 159 days.

1919. Annual report of the government entomologist for 1918-1919. Jamaica Dept. Agr. Amn. Rept. for year ended 31st. Mar. 1919, p. 28.

Note stating that two consigmments of Plaesius javanus from Java were received but most of them died on the way.

Rivera, E. IM. 1927. Informe sobre el trabajo de estudios del gorgojo del ñame del banano. Rev. Agr. Puerto Rico $19(2): 59-62,1$ fig., 1 map.

Description of a survey to determine the presence and abundance of the insect in three distriets in the Island.

Rodríguez Barrera, J. 1928. El banano, pp. 82-83 [Manual del agricultor en Fernando Póo, III, Madrid].

Brief account.

Sasscer, E. R. 1915. Important insect pests collected on imported nursery stock in 1914. Jour. Econ. Ent. 8(2) : 269.

Records a single specimen in a plant from Brazil, which in several months finally caused the plant to die down.

1916. Important foreign insect pests collected on imported nursery stock in 1915. Jour. Econ. Ent. 9:218.

"Plants from the Philippines found to be severely in. fested."

Schultze, W. 1915. A catalog of Philippine coleoptera. Nanila. Philippine Jour. Sei. 11, Sec. D., p. 148.

listed from Isuzon, Mindanao and Palawan. 
Seín, Jr., F. 1923. El gorgojo del ñame del guineo. $\mathbb{P}$. R., In's. Exp. Sta. Circ. 82, 7 pp., 2 figs.

Brief general account.

1929. El gorgojo del name del guineo en Puerto Rico. EI Nundo (San Juan, P. R.), Oct. 6, p. 15., 4 figs.

Popular account of life history, injuries, and control.

Simmonds, H. W. 1920. Report on mission to Tahiti to investigate the parasites of the coconut scale with a view to their introduction into Fiji. Cire. Info. Fiji Dept Agr. 1(7): 137 .

Recorded as doing considerable damage in the Cook Is lanis.

1921. Histerid Beetle, Plaesius javanus. Agr. Cire. Dept. Agr. Fiji 2(3): 44 .

Recovery of $P$. javanus eight years after being introduced.

1922. Coconuts and banana's on certain islands around the coast of Vitilevu. Agr. Circ. Dept. Agr. Fiji 2(5): 102-104: (1921).

Generally present but not very injurious; worse where ary than where wet.

1922. Introduction and notes. Agr. Cire. Dept. Agr. Fiji 2(5) : 111 (1921).

Very injurious at Nasinau; trapping stated to be fairly effective.

1922. Visit to Fotuna and Wallis Island. Agr. Cire. Dept. Agr. Fiji 3(2): 20.

Reported as not present.

1922. Entomological Division. Dept. Agr. Fiji Ann.

Rept. for the year 1921. Council Paper 56, p. 7.

Poor condition of banana industry largely due to attacks of weevil; trapping eaught large numbers of the weevils; believes $P$. javanus now cstablished.

1923. Report by the government entomologist. Dept. Agr. Fiji Ann. Rept. for the year 1922. Council Paper No. 46, p. 4.

Additional specimens of $P$. javanus recovered in the field. 
1924. Report on Mission to New Guinea, Bismardss, Solomons and New Hebrides. Legislative Council Fiji, Council Paper, Suva, February.

Reported as abundant in New Hebrides. (Rev. Appl. Thnt. 12: 300,1924 .)

1929. Some experiments to ascertain the part played by flight in the dispersal of the banana borer, Cosmipolites sordidus in Fiji. Agr. Jour. Dept. Agr. Fiji, 1(3) : 22-26 (1928).

Flight very oceasional and a negligible factor in dispersal.

* Small, W. 1921. Annual report of the acting entomologist for 1919-20. Uganda Dept. Agr. Ann. Rept. 191920 , p. 41 .

Statement that inquiries had been received with reference to C. sordidus. (Rev. Appl. Ent. 9: 319, 1921.)

Smith, F. E. V. 1929. Report of the acting government entomologist. Ann. Rept. Jamaica Dept. Agr. for year ended 31st. Dee. 1929, p. 20.

Continues troublesome, especially in "ratoon" fields; paradichlorobenzene not so satisfactory as previousy expected.

Smith, R. C. and Audant, A. 1930. The more important injurious insects of Haiti. Jour. Econ. Ent. 23(6) : 976 . "Widely distributed and serious."

* Sturm, J. 1826. Catalog meiner Insecten-Sammlung. (Vorzeichniss der. . vörrathigen Insecten) Thl. 1. Nürnberg. Käfer. pp. VIII, 207 (16), 4 pIs. Col, $8^{\circ}$.

Swezey, 0. H. 1924. Notes on insect pests in Samoa. Hawaiian Planters' Rec. 28(2) : 217-218.

Brief; the insect probably only recently established and not as yet generally distributed; injury briefly deseribed; scrious in Fiji and control difficult.

Torres, I. L. 1927. El gorgojo del name del guineo (Cosmopolites sordidus). Rev. Agr. Puerto Rico 9(2)56-58, 2 figs., August.

General popular account for Porto Rico. 
Tryon, H. 1917. Report of the entomologist and vegetable pathologist. Queensl. Ann. Rept. Dept. Agr. \& Stock for $1916-1917$, p. 51.

Brief́ statement of distribution in Queensland; has occasioned proelamation of a special Regulation for its suppression but still very prevalent locally.

1920. The banana weevil (Cosmopolites sordida Chevr.; Considerations influencing methods of repression. Queensl. Agr. Jour. 13(5) : 222-223.

Good description of methods of use of (a) traps, (b) removal of infested suckers, $(c)$ destruction of beetles by starvation, $(d)$ reducing egg-laying.

Tryon, H. and Benson, A. H. 1920. The banana weevil (Cosmopolites sordida Cherr.) Queensl. Agr. Jour. 13 (4) : 165-168, 5 figs.

Brief gencral aecount.

* Urich, F. W. 1916. Insect pests in Trinidad. Entomologist's Rept. Minutes Meet. Bd. Agr. 'Trinidad, pp. 1-56.

Reported from some Inealities in 'T'rinidad; recomments destruction of infested stools, ploughing, forking and liming land; the Histerid beetle will be tried. (Rev. Appl. Ent. $5: 171,1917$ ).

* 1925. The plantain weevil. Bul. Dept. Agr. Trinidad and Tobago, 21(1): 40-42, $1 \mathrm{pl}$.

General account for Trinidad; the usual control measures recommended, including submerging stekers in water for 48 lours (Rev, Appl. Ent. 14: 176, 1926).

Veitch, Robert. 1926. Report of the ehief entomologist. Ann. Rept. Dept. Agr. and Stock Queensland for 1925$1926: 135$.

Mention of publication of complete account as Bul, 4 and four introductions of Plaesius javanus noted.

1927. Report of the chief entomologist. Anm. Rept. Dept. Agr. and Stock Queensland for 1926-1927:69.

Brief mention of history of investigations; trapping with Paris green baits best; Plaesius javanus introductions apparently established. 
1928. Report of the chiet entomologist for year ending June 30, 1928. Dept. Agr. and Stock Queensland (as a separate publication of $8 \mathrm{pp}.), \mathrm{p} .1$.

Mention of Frogatt's trip to Java to import the preda. tors-Chrysopila ferruginosa Weirl and Plaesius javanus Er.

Veitch, R. and Simmonds, J. H. 1929. Pests and diseases of Queensland fruits and vegetables. Queensland Dept. Agr. and Stock, pp. 106-112, pls. 26 and 27.

Full aecount.

Walters, E. A. 1926. Control of insect pests. Rept. Agr. Dept. St. Lucia, 1924, p. 9.

Widely distributed throughout the Colony and attacks an kinds of bananas; digging out and ehopping up infested stools and soaking in lime water for 48 hours were both used.

1926. Viahility of the weevil (C'osmopolites sordidus Germar) and the banana borer (T'omarus bituberculatus Beaud.) Rept. Agr. Dept. St. Lucia for 1925, p. 8.

Immersing weevils for 48 hours in water not effective; soaking infested plants in line water for 48 hours recommended and has been adopted.

Ward, F. S. 1930. Banana growing in Malaya and the presence of diseases. Malayan Agr. Jour. 18(2): 70 .

Greatest damage on poor soils; refers to suggestion of Dr. Wardlaw who thinks this insect may be an important accessory factor as a wounding agency in contection with Panama disease and refers also to experiments of Dr. Wardlaw of Imp. Col. Trop. Agr. (Tritidad) that innoculation experiments show that the borer enters the rhizome after the disease is established.

Watts, Sir Francis. 1917. Banana borer. Jour. Jamaica Agr. Soc. $21: 169-173$.

Deseription by the Commissioner of Agrieulture of $W$. Indes of distribution in St. Andrews section, injury, ete., of weevil; contends attacks primarily weakened plants; need thoro survey and researel.

Whitney, L. A. 1927. Report of the division of plant inspection, January 1925-December 1926. Rept. Bd. Agr. \& Forestry Hawaii $1925-1926$, pp. 48-57.

Brief note recording intereeption on abaca plants (Musa textilis) from the Philippines. 
Wolcott, G. N. 1922. Informe anual de la división de entomología para el año fiscal de 1921 a 1922 . Informe An. Eist. Exp. Ins. Río Piedras, Puerto Rico, 1921-192\%, pp. 59-60. (Also in English ed., pp. 48-49, 1923.)

Brief account of discovery in Porto Rico (Dec. 1, 1921); life history, injury and control.

1922. Vaquitas de importancia económica en Puerto Rico. Porto Rico Ins. Exp. Sta. Circ. 60, pp. 11-12, 2 figs.

Brief deseription of injury; recommends attracting and destroying weevils by means of freslily sliced rhizomes.

1924. Entomología económica puertorriqueña. Est. Exp. Ins. Puerto Rico Bol. 32: 58-59.

Brief general account.

1924. Insectae portoricensis. Jour. Dept. Agr. Porto Rico 7(1): 135 (1923).

Listed from several localities in Porto Rico.

1924. Annual report of the division of entomology for the fiscal year 1922-23. Ann. Rept. Ins. Exp. Sta. Porto Rico, fiscal year $1922-3$, p. 55 .

Experiments interrupted but preliminary results indicate that daily collections from traps must be continued for several months before improvement of plants is shown.

1926. Insect pests in Haiti. Internat. Rev. Sci. \& Pract. Agr. N. S. 4(1) : 188 .

"Bananas are attacked by the root borer, Cosmopolites sordidus Germar.

1927. Entomologie d' Haiti. Published under the direetion of the Service Technique, Dept. Agr. Haiti, pp. 253-256, 391-392, 2 figs.

Brief general account; generally distributed thruout Haiti. 